\title{
Paraneoplastic neurological syndromes
}

\section{Introduction}

Almost any part of the nervous system can be affected by paraneoplastic syndromes (table 1). It is important to recognise paraneoplastic neurological syndromes (PNS), for several reasons. They usually predate symptoms of the malignancy, and identification should lead to a search for the primary tumour. PNS may also predate the clinical appearance of metastatic deposits or tumour recurrence. In a patient with a diagnosed malignancy there is a tendency to consider effects at remote sites to be considered as secondary deposits, and the patient may be deprived of appropriate therapy owing to an incorrect diagnosis of multiple secondary deposits. Most of the PNS are of immunological aetiology, but immunosuppression is not beneficial except in a few. Appropriate treatment for the primary tumour usually helps in improving the PNS symptoms.

\section{Pathogenic mechanisms}

Many non-neurological paraneoplastic syndromes are due to the effects of hormones or peptides produced by the tumour. But PNS are commonly immune mediated. Ectopic expression of neural antigens by the tumour gives rise to formation of antibodies against them. These in turn attack the neural tissues through humoral or T-cell mediated mechanisms. Cerebrospinal fluid (CSF) analysis may show evidence of intrathecal immunoglobulin synthesis. And tumours which give rise to PNS are often infiltrated with inflammatory cells making identification difficult. 


\section{Table1. Paraneoplastic syndromes affecting different sites of the nervous system}

Muscle

Polymyositis or dermatomyositis

Necrotising myopathy

Myotonia

Polymyalgia rheumatica

Neuromuscular junction

Myasthenia gravis

Lambert-Eaton myasthenic syndrome

Peripheral nerves

Polyneuropathy or radiculopathy

(Guillain-Barre syndrome)

Plexopathy (brachial neuritis)

Chronic sensory motor neuropathy

Autonomic neuropathy

Vasculitic neuropathy

Neuromyotonia

Anterior horn cells

Amyotrophic lateral scleroisis

Stiff-man (stiff-person) syndrome

Dorsal root ganglia

Sensory neuronopathy

Spinal cord

Nectrotising myelopathy

Transverse myelitis

Subacute motor neuronopathy

Cerebellar

Cerebellar degeneration

(Subacute cerebellar ataxia)

Brain

Limbic encephalitis

Brainstem encephalitis

Opsoclonus myoclonus

Cranial nerves

Retinopathy
A cause and effect relationship with antibodies is observed in some syndromes. Antibodies against P/Q type voltage-gated calcium channels in myasthenic myopathic (Lambert-Eaton) syndrome can explain the preganglionic block at the neuromuscular junction with muscle weakness. Anti-acetylcholine receptor antibodies in myasthenia gravis and antibodies against voltage-gated potassium channels in neuromyotonia are other examples. In many PNS affecting the brain the cause and effect relationship cannot be directly demonstrated although there is evidence of inflammation.

\section{Diagnosis}

Clinical features of PNS are not particularly different from similar syndromes due to non-paraneoplastic causes. Some clues such as the time course of cerebellar degeneration and severe pain with neuropathy may raise suspicion but are not useful in themselves for accurate diagnosis.

CSF analysis gives a clue to immunological aetiology in the nervous system eg. an oligoclonal band and pleocytosis. Results of the neurophysiological investigations such as electromyography (EMG), nerve conduction studies, repetitive stimulation and single fibre EMG are useful in confirming the clinical syndrome but do not support a paraneoplastic aetiology. Magnetic resonance imaging (MRI) may show structural changes in limbic encephalitis and changes of cerebellar atrophy within a few months.

Detection of paraneoplastic antibodies helps to diagnose PNS. Most of the antibodies are present in serum, hence detection in the CSF is not essential. As shown in table 2 some antibodies are specific for tissues regardless of the aetiology of the PNS. Myasthenia gravis and myasthenic syndrome can occur without an association with PNS. Sometimes the presence of antibodies is a strong pointer to a PNS aetiology, as in the case of anti-Hu antibodies.

If antibodies are detected investigations can be focused on the likely organs (see table 2).

In the absence of clues from clinical examination and antibody tests, high resolution CT scan of the chest, abdomen and pelvis, whole body fluorodeoxyglucose positron emission tomography (FDG-PET), PET/CT, mammography, testicular ultrasonography and MRI may be useful. If all are negative, review at every 3 months for up to 3 years is recommended.

\section{Diagnostic criteria}

Because of the difficulties in diagnosis patients with suspected PNS may be classified as "definite" and "probable". 
Table 2. Antibodies associated with paraneoplastic neurological syndromes

\begin{tabular}{|c|c|c|}
\hline Antibodies & Clinical syndrome & Associated cancer \\
\hline $\begin{array}{l}\text { Acetylcholine receptor } \\
\text { antibodies(Anti-AChR) }\end{array}$ & Myasthenia gravis & Thymoma \\
\hline Anti-nAchR & $\begin{array}{l}\text { Paraneoplastic autonomic } \\
\text { neuropathy }\end{array}$ & SCLC* \\
\hline $\begin{array}{l}\text { Antibodies against voltage- } \\
\text { gated calcium channels } \\
\text { (Anti-VGCC) }\end{array}$ & $\begin{array}{l}\text { Lambert-Eaton myasthenic } \\
\text { syndrome (LEMS) }\end{array}$ & SCLC \\
\hline $\begin{array}{l}\text { Antibodies against } \\
\text { voltage-gated potassium } \\
\text { channels (Anti-VGKC) }\end{array}$ & $\begin{array}{l}\text { Neuromyotonia, } \\
\text { limbic encephalitis }\end{array}$ & Thymoma, SCLC \\
\hline $\begin{array}{l}\text { Antibodies against cytoplasm } \\
\text { of Purkinje cells Anti-Yo } \\
\text { (PCA1) }\end{array}$ & Subacute cerebellar degeneration & $\begin{array}{l}\text { Ovarian, breast and } \\
\text { lung cancers }\end{array}$ \\
\hline (PCA2) & $\begin{array}{l}\text { Subacute cerebellar degeneration, } \\
\text { encephlaomyelitis }\end{array}$ & SCLC \\
\hline $\begin{array}{l}\text { Anti-neuronal nuclear } \\
\text { antibody Anti-Hu (ANNA 1) }\end{array}$ & $\begin{array}{l}\text { Encephalomyelitis, } \\
\text { limbic encephalitis, } \\
\text { sensory neuronopathy, } \\
\text { cerebellar degeneration, } \\
\text { autonomic neuropathy }\end{array}$ & $\begin{array}{l}\text { SCLC, prostate cancer, } \\
\text { neuroblastoma }\end{array}$ \\
\hline Anti-Ri (ANNA 2) & $\begin{array}{l}\text { Opsoclonus-myoclonus, brainstem } \\
\text { encephalitis, ataxia }\end{array}$ & Breast, ovary, bladder \\
\hline ANNA 3 & $\begin{array}{l}\text { Encephalomyelitis, } \\
\text { sensory neurnopathy }\end{array}$ & SCLC \\
\hline Anti Ma-1 & $\begin{array}{l}\text { Limbic encephalitis, } \\
\text { brainstem encephalitis, } \\
\text { subacute cerebellar } \\
\text { degeneration }\end{array}$ & Testicular cancer \\
\hline Anti-amphiphysin & $\begin{array}{l}\text { Stiff person syndrome, } \\
\text { encephalomyelitis, } \\
\text { sensory neuronopathy, } \\
\text { sensory motor neuropathy }\end{array}$ & Breast, SCLC \\
\hline Anti-Tr(PCA-Tr) & Subacute cerebellar degeneration & Hodgkin lymphoma \\
\hline Anti-mGlu R1 & Subacute cerebellar degeneration & Hodgkin lymphoma \\
\hline Anti-recovering & Retinopathy & $\begin{array}{l}\text { SCLC, melanoma, } \\
\text { gynaecological cancers }\end{array}$ \\
\hline
\end{tabular}

* SCLC $=$ small cell lung cancer 
Table 3. Symptomatic paraneoplastic neurological syndromes

\begin{tabular}{|c|c|c|}
\hline Syndrome & Clinical features & Associated tumors \\
\hline Limbic encephalitis & $\begin{array}{l}\text { Subacute confusion, short term memory } \\
\text { loss, psychiatric symptoms related to limbic } \\
\text { system, seizures, hyperthermia and } \\
\text { endocrine abnormalities due to } \\
\text { hypothalamic involvement }\end{array}$ & $\begin{array}{l}\text { SCLC, testicular tumours, } \\
\text { breast cancers, Hodgkin } \\
\text { disease and thymoma }\end{array}$ \\
\hline Brainstem encephalitis & $\begin{array}{l}\text { Diplopia, dysarthria, dysphagia, gaze } \\
\text { abnormalities; nuclear or internuclear, } \\
\text { facial numbness, subacute hearing loss }\end{array}$ & SCLC \\
\hline Subacute cerebellar ataxia & $\begin{array}{l}\text { Nausea, vomiting, dizziness, developing } \\
\text { rapidly with dysarthria, gait abnormalities } \\
\text { and incoordination }\end{array}$ & $\begin{array}{l}\text { SCLC, ovarian malignancy, } \\
\text { Hodgkin lymphoma }\end{array}$ \\
\hline Opsoclonus-myoclonus & $\begin{array}{l}\text { Involuntary arrhythmic, high amplitude, } \\
\text { gross conjugate saccades in all directions, } \\
\text { no remission in darkness or with eye closure, } \\
\text { remissions and relapses, increased } \\
\text { startle reaction }\end{array}$ & $\begin{array}{l}\text { SCLC, breast, ovarian, } \\
\text { neuroblastoma (in children), } \\
\text { thyroid, bladder }\end{array}$ \\
\hline Necrotizing myelitis & $\begin{array}{l}\text { Paraparesis with sphincter involvement, } \\
\text { which is rapidly ascending to involve the } \\
\text { brainstem }\end{array}$ & \\
\hline Subacute sensory neuronitis & $\begin{array}{l}\text { Rapidly progressing and disabling pain, } \\
\text { paraesthesia, clumsiness and unsteady gait, } \\
\text { asymmetrical or multifocal sensory loss of face } \\
\text { and abdomen, sensory loss for all modalities, } \\
\text { absent tendon reflexes }\end{array}$ & $\begin{array}{l}\text { SCLC, breast, ovarian sarcoma } \\
\text { Hodgkin lymphoma }\end{array}$ \\
\hline Encephalomyelitis & $\begin{array}{l}\text { Features of limbic encephalitis, brainstem } \\
\text { encephalitis, cerebellum, myelitis and the } \\
\text { sensory neuronitis }\end{array}$ & SCLC \\
\hline LEMS & $\begin{array}{l}\text { Proximal muscle weakness, dry mouth, autonomic } \\
\text { dysfunction, absent reflexes which get augmented } \\
\text { after isotonic contraction or repeated tapping }\end{array}$ & $\begin{array}{l}\text { SCLC (without PNS } \\
\text { also reported) }\end{array}$ \\
\hline Dermatomyositis & $\begin{array}{l}\text { Heliotropic rash, proximal muscle weakness } \\
\text { and pain, arthralgia, myocarditis }\end{array}$ & $\begin{array}{l}\text { Ovary, colorectal, gastric, } \\
\text { breast, pancreas, non-Hodgkin } \\
\text { lymphoma }\end{array}$ \\
\hline $\begin{array}{l}\text { Neuromyotonia } \\
\text { (peripheral nerve } \\
\text { hyperexcitability) }\end{array}$ & $\begin{array}{l}\text { Cramps, fasciculations, motor weakness, } \\
\text { hyperhydrosis, EMG fibrillations, } \\
\text { myokimic discharges }\end{array}$ & Thymoma, SCLC \\
\hline
\end{tabular}




\section{Definite PNS}

a. A classical syndrome (eg. LEMS, dermatomyositis), with cancer developing within 5 years of the diagnosis of PNS.

b. A non-classical syndrome which does not remit spontaneously, but objectively improves or resolves after cancer treatment.

c. A non-classical syndrome with paraneoplastic antibodies, and cancer that develops within 5 years of the diagnosis of PNS.

d. A neurological syndrome (classical or not) with wellcharacterized paraneoplastic antibodies.

\section{Probable PNS}

a. A classical syndrome without paraneoplastic antibodies and no cancer but at high risk to have an underlying tumour (eg. heavy smoker).

b. A neurological syndrome (classical or not) without cancer but with partially characterised paraneoplastic antibodies.

c. A non-classical neurological syndrome, with no paraneoplastic antibodies, but cancer that presents within 2 years of the neurological syndrome.

\section{Clinical features}

Symptomatic PNS are rare. They include LEMS (3\% of SCLC), myasthenia gravis (15\% of thymoma), and demyelinating peripheral neuropathy (10\% of myeloma with monoclonal gammopathy and nearly $50 \%$ of osteoclastic myeloma). If routine electrophysiological studies are included in evaluation the proportion of patients with PNS is likely to be higher. Clinical features and electrophysiological abnormalities of some syndrome are listed in table 3 .

\section{Treatment}

As the pathogenic mechanisms are immune mediated removing the antigenic source (ie. the tumour), and immunosuppression, or removing the antibodies should be effective. Removal of primary tumour is effective. Immunosuppression is known to be effective only in a few syndromes such as myasthenia gravis, LEMS and stiff-person syndrome. In myasthenia gravis and LEMS, plasma exchange and immunoglobulin are effective. In T-cell mediated diseases such as subacute cerebellar degene-ration and encephalomyelitis tacrolimus or mycophenolate mofetil can be tried. Dermatomyositis can be treated with steroids and azathioprine. Although there are no standard protocols for immunotherapy for PNS many physicians combine plasma exchange, immunoglobulins, steroids and other immunosuppressives when the clinical condition deteriorates.

Symptomatic treatment may be beneficial in some syndromes. In myasthenia gravis pyridostigmine or neostigmine are beneficial whereas in neuromyotonia, phenytoin sodium may help.

\section{Prognosis}

PNS like myasthenic syndrome responds well to immunosupression and removal of tumour. Peripheral neuropathy due to osteoclastic myeloma improves with radiotherapy. Opsoclonus myoclonus responds to tumour removal or immunosupression or both. The prognosis of encephalomyelitis is poor but there may be some response to tumour removal.

The differences in prognosis and response to treatment can be explained on the underlying pathogenic mechanisms. In LEMS there is no neuronoal loss although the function of the nerve is blocked. In encephalitis there is neuronal cell damage caused by intracellular antibodies.

\section{Further reading}

1. De Beukelaar JW, Sillevis Smitt PA. Managing paraneoplastic neurological disorders. Oncologist 2006; 11: 292-305.

2. Daniel RB, Posner JB. Paraneoplastic syndromes involving the nervous system. New England Journal of Medicine 2003; 349: 1543-54.

3. Rosenfeld MR, Dalmau J. Paraneoplastic disorders of the nervous system. In: Neurology in Clinical Practice. London: Butterworth-Heinemann, 2004.

4. Graus F, Delattre JY, Antoine JC, et al. Recommended diagnostic criteria for paraneoplastic neurological syndromes. Journal of Neurology, Neurosurgery and Psychiatry 2004; 75: $1135-40$.

K D Pathirana, Department of Medicine, Faculty of Medicine, University of Ruhuna, Sri Lanka.

Correspondence: KDP, e-mail: <kithsiripathirana@yahoo.com>. Competing interests: none declared. 